\title{
Education Access Coverage Of State Junior High Schools As The Impact Of Zoning Policy In Indonesia
}

\author{
Isrokatun \& Leli Yulifar \\ Universitas Pendidikan Indonesia \\ isrokatun@gmail.com
}

\begin{abstract}
The implementation of zoning policy through the regulations of Minister of Education and Culture No. 51 in 2018 raises new problems in Indonesia. Some of these problems are also experienced by people in Cimahi. This research is motivated by the need for the local government of Cimahi to restructure and rearrange the adequacy of State Elementary Schools graduates to enroll State Junior High Schools in Cimahi. This qualitative descriptive research was carried out by processing data, organizing, analyzing, summarizing, and describing the conditions as they are related to the zoning map data for the 2019/2020 academic year of Cimahi. Zoning map for the 2019/2020 school year, the draft of local regulations of Cimahi, and also Minister of Education and Culture No. 51 of $2018 \mathrm{r}$ concerning admission of new students are processed and analyzed qualitatively to see how adequate the access of education at State Junior High Schools seen from the number of its graduates that can be accommodated, as the effect of zoning policy. From the results of data analyzing, the conclusions are: 1) there is not yet adequate access to education at the State Junior High School level when it is compared to the number of graduates from State Elementary Schools; 2) from the nine zones in the zoning map of Cimahi, there were only 6 graduates from State Elementary Schools that can be accommodated in State Junior High Schools; and 3) there are still a large number of Elementary Schools graduates for the 2019/2020 school year who have not been accommodated in the zoned State Junior High Schools. Therefore, from the result of this study, it can be recommended that the increase in the number off class units is still needed, and the development of New School Units for State Junior High Schools which refers to laws and regulations, which to organize the zoning system in Cimahi in the form of Mayor Regulations.
\end{abstract}

Keywords: Zoning policy, Cimahi, Education access coverage

\begin{tabular}{ll}
\hline Article History & Received : August $7^{\text {th }} 2020$ \\
& Revision : October $11^{\text {th }} 2020$ \\
& Publication : Dec 30th 2020 \\
\hline
\end{tabular}

\section{INTRODUCTION}

One of the variables that can support sustainability figure and the quality of education is the resolution of problems related to the admission of new students with a zoning system. This problem is so important to be resolved in particular province in Indonesia., the Governor requires that the candidate for the Head of Education Office should be those who can solve problems related to the implementation of zoning system in admission of new students, as it is mandated by laws or regulations in admission of new 
students. The regulations itself related to the regulations of Minister of Education and Culture No. 51 of 2018 (as substitution to the regulations of Minister of Education and Culture No. 17 of 2017 and the regulations of Minister of Education and Culture No. 14 of 2018), which then it becomes the legal basis for implementing new students admission in 2019. The hope is that the various 'impacts' of policies in new students admission, which in most parts of Indonesia experienced 'chaos' can be resolved soon. Some of the 'impact', for example related to the policy of Certificate of Incapability, old domicile rules, distance, and etc. the goal is that all educational problems such as the availability of school facilities, equal teachers distribution, and also distribution of students that lead the equity of education in Indonesia. And those problems also happened in Cimahi.

Cimahi is one of municipality in West Java Province, Indonesia. This is located in the middle of Bandung Regency and West Bandung Regency. Cimahi used to bepart of Bandung regency which was later designated as an administrative city on January, 1976 and became municipality on June 21, 2001.

One of the most important things in certain area is social services that becomes basic needs. The accessibility of educational facilities in Cimahi such as Kindergartens, Elementary Schools, Junior High Schools and Senior High Schools. The facilities in Cimahi consists of 125 units Elementary Schools and 21 units Islamic Elementary School (Madrasah Ibtidaiyah), 38 units of Junior High Schools and 16 units of Islamic Junior High School (Madrasah Tsanawiyah) and 16 units of Senior High Schools, 9 Islamic Senior High School (Madrasah Aliyah) and 24unit of Vocational Schools, with various distribution patterns of educational facilities in each sub-district. Therefore, the efforts of the Mayor in overcoming educational problems are a crucial part of getting the attention from various parties and for this case is the Education Office and stakeholders and also the support from community.

The impact of zoning system in New Students Admission in Cimahi, including the emergence of several problems that lead to the need to structuring Elementary and Junior High Schools level. Starting from a study that aims to identify alternative solutions to problems related to the arrangement of State Elementary Schools graduates to be able to enroll State Junior High Schools based on zoning regulations, the adequacy of graduates who can be accepted in State Junior High Schools in Cimahi based on zoning regulation, analyzing the zoning regulations in Cimahi, and identifying Elementary Schools graduates who have been accommodated in State Junior High School because of the system itself.

Before the implementation of the regulations of Minister of Education and Culture No. 17 of 2017 (which was later revised to the regulations of Minister of Education and Culture No. 14 of 2018) concerning new students admission, the Cimahi community in a school area generally did not only cover schools in their area only but sometimes headed to schools in other places that were close to or those that far from where they live with certain personal considerations. This condition is supported by the absence of zoning regulations in Cimahi. Means that people from certain sub-district or regency do not have to go to school to where they live. The community is free to determine schools for their 
children whether it is out of the sub-district or not. This condition causes the distribution of students unevenly. It is caused by parents send their children to schools that they assume better that other schools. From these conditions, it can cause a serious problem. There is an interest in sending their children to particular schools, causing problems in equal distribution and also the quality in both Elementary and Secondary education levels, it emerges certain phenomenon of economical gap of favorite schools )between the rich and the poor, between the good and bad ones)

Taking into account this phenomenon, it is clear that the coverage to education center is crucial component in educational system. Therefore, the implementation of educational services focuses on the aspect of equity and the level of community needs and needs a good strategy so that can meet the educational services as well. This has been successful as exemplified in Japan and Italy in implementing zoning system (Mustholih, 2019). The zoning system allows students to get equal coverage and quality of education. This system can eliminate school favoritism. Moreover, students are physically healthier, because they walk to school. Or if their houses are about 2-5 kilometers away. They only need to ride a bike. It is rare for the parents to take their children by car to schools. They prefer to accompany them to walk together to go to school. The bond between parents and children in education is more visible. A scene like this is very common in Japan (Koesoema, 2018). It can also be seen in Finnish education system, that there is an increase in the students learning process which is achieved by the existence of an education policy based on equality and flexibility (Sahlberg, 2007).

In 2018, Cimahi began implementing a zoning system as it is mandated by the regulations of Minister of Education and Culture No. 17 of 2017. This applicaton includes Public Elemantary Schools Unit and the spirit of implementing these regulations which are non-discriminative, objective, transparent, accountable and fair. It also happens in New Zealand that the purpose of zoning system is to achieve equality in schools facilities (McCulloch, 1991)

However, based on interviews in the field, it is known that there is no regulations in the form of Mayor's Decree, and zoning rules are still unclear for stakeholder to understand. Cimahi experiences various problems in implementing the regulations of Minister of Education and Culture. Among them, there is still a group of people who stay in area which is not belonged to any zones so that their children cannot enroll to any schools. It is vice versa, there is also a group of people belonged to more than one zone (double zone).

In addition, there are other cases that have emerged as in other areas in various cities/districts in Indonesia. It arouse in case of implementing zoning system such as the use of Certificate of Incapability is unclear and the alleged abuse of permit as the perquisite for certain clauses of the regulations of Minister of Education and Culture No. 17 of 2017. From several problems that emerged in the implementation of zoning system there is a wayout especially for Elementary and Junior High School level through the 
rearrangement of the number of class groups in each zone so the graduates can be accommodated in each zone.

Therefore, a study is needed to be used as a basis in formulating policies related to the coverage of education access of Junior High Schools for Elementary Graduates as the effect of zoning system in Cimahi. The formulations of the problems in this study are 1) How is the coverage education access in Junior High Schools level if it is compared to the number of graduates from Elementary schools in each zone in Cimahi, 2) How to analyze the coverage of Elementary Schools graduates who can be accommodated in Junior High School in Cimahi in each related zone.

\section{METHOD}

This research is a qualitative descriptive study. This study does not provide treatment, manipulation or alteration to the studied variables, but only describe a condition as it is related to the implementation of the zoning system in Cimahi.

According Komariah \& Satori (2011) descriptive qualitative study is done to explore phenomena that cannot be quantified that is a study of education access coverage of state JHS as the impact of zoning system in Cimahi. In addition, the study is also to describe phenomena which are exist both natural and artificial which give more attention to characteristics and quality of zoning system that is implemented in Cimahi (Sukmadinata, 2011)

Data collection technique is carried out by collecting files and documents related to zoning system in term of its distribution in Cimahi and also in term of New Students Admission for 2019/2020 school year. Through the document itself then data processing and analyzing are carried out with the help of Microsoft Office Excel 2010 based on:

1. Zoning system regulations, from zone 1 till zone 9

2. Looking at the proportion of the ration between elementary school graduates and the capacity of JHS in each zoning.

3. Looking at the proportion of the ratio between elementary school graduates and who receive PKH (Program Keluarga Harapan) with the capacity of JHS in each zone.

4. Looking at the coverage between elementary school graduates and the capacity of JHS in each zone.

5. Looking at from the unfulfilled capacity for JHS to accept elementary school graduates in Cimahi.

6. Looking at from the unfulfilled capacity for JHS to accept elementary school graduates in Cimahi plus students who receive PKH (Program Keluarga Harapan)

7. Suggestions and recommendations that can be given so that the coverage education access can be serve optimally.

Data collection technique was done through collecting related documents, such as:

1. The concept of distribution of zoning area in Cimahi in term of New Students Admission in 2019/2020 school year. 
2. Local Government Regulations No of 2018 about the management of Elementary Level

3. The regulations of Minister of Education and Culture No. 51 of 2018 about New Students Admission

From those documents then the data were processed and analyzed with the help from Microsoft Office Excel 2007 which is based on:

1. Zoning system regulations, from zone 1 till zone 9

2. Total number of elementary schools in Cimahi based on the zone.

3. Total number of JHS and the its capacity in Cimahi

4. Analyzing the comparison between number of elementary and JHS in each zone in Cimahi

5. Analyzing the number of school age of elementary school and capacity of JHS

6. Discussing and presenting how are the rules in Cimahi

7. Summarizing zoning map in term of New Students Admission for Elementary and JHS in Cimahi

8. Analyzing the education access coverage in JHS compared with related school age based on zone in Cimahi

Arranging suggestions and recommendations towards the study of new school building of JHS in Cimahi so the education services can be given optimally.

\section{RESULTS AND DISCUSSION}

These are the result of the research and discussion from zoning map in Cimahi in term of New Students Admission in 2019/2020 school year, they are:

1. Total number of State Elementary School and JHS in Cimahi.

As an explanation, the total number of State elementary schools and JHS is as follows:

Table 1. State Elementary School Units in Cimahi

\begin{tabular}{|c|c|c|c|c|}
\hline Zone & \begin{tabular}{|c|} 
Number \\
of State \\
Element \\
ary \\
School \\
Units
\end{tabular} & Details & $\begin{array}{c}\text { Students } \\
\text { Number } \\
\text { of Class } 6\end{array}$ & $\begin{array}{c}\text { PKH } \\
\text { Recipients }\end{array}$ \\
\hline 1 & 10 & $\begin{array}{l}\text { SD N Melong Mandiri 1, 2, 3, 4, 5, 6; } \\
\text { SD N Melong Asih 4, 5, 7, and 8 }\end{array}$ & 825 & 115 \\
\hline 2 & 7 & $\begin{array}{l}\text { SD N Cibeureum Mandiri 1, 2; SD N } \\
\text { Cibeureum 5, 7; SD N Tunas Mekar; } \\
\text { SD N Tunas Harapan; SD N } \\
\text { Rancabentang }\end{array}$ & 504 & 164 \\
\hline 3 & 12 & $\begin{array}{l}\text { SD N Cibeber 1, 2, 3, 4; SD N Cibeber } \\
\text { Mandiri 2; SD N Leuwigajah 2, 3, 5, }\end{array}$ & 572 & 128 \\
\hline
\end{tabular}


Volume 4 Number 2 December 2020

\begin{tabular}{|c|c|c|c|c|}
\hline & & $\begin{array}{l}\text { 6; SD N Kahipit; SD N Linggabudi; SD } \\
\text { N Cireundeu }\end{array}$ & & \\
\hline 4 & 12 & $\begin{array}{l}\text { SD N Melong Mandiri 7; SD N } \\
\text { Kebonsari 1, 2; SD N Baros Mandiri } \\
\text { 3; SD N Utama 3, 6, 7; SD N Utama } \\
\text { Mandiri 1; SD N Cibodas 1, 2, 3; SD N } \\
\text { Leuwigajah Mandiri } 1\end{array}$ & 707 & 97 \\
\hline 5 & 5 & SD N Baros Mandiri 1, 2, 4, 5, 6 & 578 & 44 \\
\hline 6 & 6 & $\begin{array}{l}\text { SD N Harapan 1, 2; SD N Padasuka } \\
\text { Mandiri 1, 3, 4; SD N Cibeber } \\
\text { Mandiri 1 }\end{array}$ & 393 & 107 \\
\hline 7 & 28 & $\begin{array}{l}\text { SD N Mandiri Cimahi 1, 2, 3, 4, 5; SD } \\
\text { N Cibabat Mandiri 1; SD N Citeureup } \\
\text { 1, 2; SD N Citeurep 2, 3; SD N } \\
\text { Cempaka; SD N Citeureup Mandiri 1; } \\
\text { SD N Mawar; SD N Bina Harapan; SD } \\
\text { N Cigugur Tengah; SD N Cimindi 2, 4, } \\
\text { 5; SD N Sindang Sari; SD N Karya } \\
\text { Bakti; SD N Budi Karya; SD N } \\
\text { Budiasih; SD N Sosial 1, 2; SD N } \\
\text { Karangmekar Mandiri 1, 2; SD N } \\
\text { Padasuka Mandiri 2; SD N Sukamaju } \\
1 \text { and } 2\end{array}$ & 2.180 & 169 \\
\hline 8 & 6 & $\begin{array}{l}\text { SD N Cipageran Mandiri 2, 3, 4; SD N } \\
\text { Setiawarga }\end{array}$ & 624 & 174 \\
\hline 9 & 13 & $\begin{array}{l}\text { SD N Cibabat Mandiri 2, 3, 4, 5; SD N } \\
\text { Cibabat 2, 4, 5; SD N Pasirkaliki 1, 2, } \\
\text { 3, 5, 6; SD N Pasirkaliki Mandiri 1 }\end{array}$ & 750 & 120 \\
\hline \begin{tabular}{|c|} 
Total \\
Numbe \\
$\mathbf{r}$ \\
\end{tabular} & & 99 & 7.133 & 1.118 \\
\hline
\end{tabular}

From the table above, it can clearly explained that from the nine zoning, there are 99 elementary schools in Cimahi with total number of students 7.133 of which 1.118 are $\mathrm{PKH}$ recipients with the distribution of each sub-district in each zone. Zoning 5 is the zoning with the least number of elementary school units, with 5 schools, with total number students 578 in sixth grade, with 44 students as PKH recipients. Meanwhile, zoning 6 is the zone with the lowest number of students 393 in sixth grade and 107 of them are PKH recipients. Zoning 7 is the biggest zoning with total number of elementary schools are 28 units and located in various sub-district with a total number of 2.180 in 
sixth grade, 169 of them are PKH recipients. Meanwhile the number of JHS and the capcity in each zone in Cimahi are as follows:

Table 2. JHS Units in Cimahi

\begin{tabular}{|c|c|c|c|}
\hline$\overline{\text { Zone }}$ & JHS & Capacity & Class Group \\
\hline$\overline{11}$ & "SMP N 4 Cimahi & 396 & $\overline{11}$ \\
\hline 2 & SMP N 7 Cimahi & 324 & 9 \\
\hline 3 & SMP N 8 Cimahi & 396 & 11 \\
\hline 4 & SMP N 9 Cimahi & 324 & 9 \\
\hline 5 & SMP N 2 Cimahi & 396 & 11 \\
\hline 6 & SMP N 3 Cimahi & 396 & 11 \\
\hline \multirow[t]{2}{*}{7} & SMP N 1 Cimahi & 396 & 11 \\
\hline & SMP N 6 Cimahi & 252 & 7 \\
\hline \multirow[t]{2}{*}{8} & SMP N 11 Cimahi & 144 & 4 \\
\hline & SMP N 5 Cimahi & 396 & 11 \\
\hline 9 & SMP N 10 Cimahi & 324 & 9 \\
\hline \multicolumn{2}{|c|}{ Total Number } & 3.744 & 84 \\
\hline
\end{tabular}

From the table above the total capacity in all zoning is 3,744 and they are divided into 84 class group. Zone 7 is a zoning with the biggest capacity because there two JHS, that is 648 with total class group 18 groups. Generally, each zone has one JHS as reference within the zone itself except zone 7 and 8 which have 2 JHS with larger capacity.

Table 3. The Comparison between Elementary School and JHS Units in Cimahi

\begin{tabular}{|c|c|c|c|c|c|}
\hline Zone & $\begin{array}{c}\text { Total } \\
\text { Number of } \\
\text { Elementary } \\
\text { School Unit }\end{array}$ & $\begin{array}{c}\text { Students } \\
\text { Number of } \\
\text { Class 6 }\end{array}$ & $\begin{array}{c}\text { PKH } \\
\text { Recipients }\end{array}$ & $\begin{array}{c}\text { Total } \\
\text { Number } \\
\text { of JHS } \\
\text { Unit }\end{array}$ & Capacity \\
\hline \hline 1 & 10 & 825 & 115 & 1 & 396 \\
\hline 2 & 7 & 504 & 164 & 1 & 324 \\
\hline 3 & 12 & 572 & 128 & 1 & 396 \\
\hline 4 & 12 & 707 & 97 & 1 & 324 \\
\hline 5 & 5 & 578 & 44 & 1 & 396 \\
\hline 6 & 6 & 393 & 107 & 1 & 396 \\
\hline 7 & 28 & 2.180 & 169 & 2 & 648 \\
\hline 8 & 6 & 624 & 174 & 2 & 540 \\
\hline 9 & 13 & 750 & 120 & 1 & 324 \\
\hline
\end{tabular}


Volume 4 Number 2 December 2020

\begin{tabular}{|c|c|c|c|c|c|}
\hline $\begin{array}{c}\text { Total } \\
\text { Number }\end{array}$ & 99 & 7.133 & 1.118 & 11 & 3.744 \\
\hline
\end{tabular}

From the table above, overall JHS in the nine zones cannot accommodate all elementary schools graduates. This is due to inadequate capacity. The total number of elementary graduates is 7,133 students while the capacity can only accept 3,744 . There are still 3,389 students who cannot be accommodated in JHS.

As PKH recipients, 1,118 students are likely to be accepted at state JHS as government effort to help poor people and to be priority in term of New Students Admission.

If we look at it, there is only zone 6 suitable which the number of elementary schools graduates can be accommodated in JHS. Meanwhile for zoning 8, not all elementary school graduate can be accommodated in JHS. This is the summary of the analysis:

Table 4. The Comparison Between the Adequacy of Capacity with Elementary School Graduates within Zoning

\begin{tabular}{|c|c|c|c|c|}
\hline Zone & $\begin{array}{c}\text { Total } \\
\text { Number of } \\
\text { Elementary } \\
\text { School Unit }\end{array}$ & $\begin{array}{l}\text { Students } \\
\text { Number of } \\
\text { Class } 6\end{array}$ & Capacity & Remarks \\
\hline$\overline{11}$ & 10 & 825 & 396 & $\begin{array}{l}429 \text { students are not } \\
\text { accommodated in JHS } \\
\text { within the zone }\end{array}$ \\
\hline 2 & 7 & 504 & 324 & $\begin{array}{l}180 \text { students are not } \\
\text { accommodated in JHS } \\
\text { within the zone }\end{array}$ \\
\hline 3 & 12 & 572 & 396 & $\begin{array}{l}176 \text { students are not } \\
\text { accommodated in JHS } \\
\text { within the zone }\end{array}$ \\
\hline 4 & 12 & 707 & 324 & $\begin{array}{l}383 \text { students are not } \\
\text { accommodated in JHS } \\
\text { within the zone }\end{array}$ \\
\hline 5 & 5 & 578 & 396 & $\begin{array}{l}182 \text { students are not } \\
\text { accommodated in JHS } \\
\text { within the zone }\end{array}$ \\
\hline 6 & 6 & 393 & 396 & $\begin{array}{l}\text { JHS within zoning there } \\
\text { still three students left }\end{array}$ \\
\hline 7 & 28 & 2.180 & 648 & $\begin{array}{l}\text { 1.532 students are not } \\
\text { accommodated in JHS } \\
\text { within the zone }\end{array}$ \\
\hline
\end{tabular}


Volume 4 Number 2 December 2020

\begin{tabular}{|c||c|c|c|l|}
\hline 8 & 6 & 624 & 540 & $\begin{array}{l}\text { 84 students are not } \\
\text { accommodated in JHS } \\
\text { within the zone }\end{array}$ \\
\hline 9 & 13 & 750 & 324 & $\begin{array}{l}\text { 426 students are not } \\
\text { accommodated in JHS } \\
\text { within the zone }\end{array}$ \\
\hline $\begin{array}{c}\text { Total } \\
\text { Number }\end{array}$ & $\mathbf{9 9}$ & $\mathbf{7 . 1 3 3}$ & $\mathbf{3 . 7 4 4}$ & $\begin{array}{l}\mathbf{3 . 3 8 9} \text { students are not } \\
\text { accommodated in JHS } \\
\text { within the zone, equals } \\
\text { to 95 class groups }\end{array}$ \\
\hline
\end{tabular}

The biggest number elementary graduates who are not accommodated in JHS is in zone 7 for about 1,532. And overall in the nine zones there are 3,389 students who have not been accommodated in JHS in Cimahi it is equals to 95 class groups. It means, if the government of Cimahi wants a policy that elementary graduates should be accommodated in JHS, it requires the provision of new classes (new school units) which is equal to 95 classes.

\section{Regulations of Zoning System in Cimahi}

As a reference, guidelines for zoning regulations in Cimahi, it follows the rules of the regulations of Minister of Education and Culture No. 51 of 2018. New Student Admission is carried out based on the regulations of Minister of Education and Culture No. 51 of 2018 which are:

1. Non-discriminative, except for school that serve students from certain gender or religious groups.

2. Objective

3. Transparent

4. Accountable

5. Fair

There are several things that become a reference for zoning regulations as it is stated in the regulations of Minister of Education and Culture No. 51 of 2018) such as:

1. Based on the domicile of the students

2. Choice of the closest school

3. School capacity in JHS

4. Pre-prosperous and general selection types (PKH recipients having certificate of incapability) and others.

5. Adjusting to the order of priority: (Media of Communication and Inspiration, 2017): 1) residence distance; 2) age; 3) Result School Scores; 4)Achievements in academic and non-academic which is recognized by the school and suits with the local authorities

The objectives of zoning regulations for Elementary graduates enroll JHS in Cimahi are: 
a. For equality of receiving rights of education for children at age school to obtain quality education (Warta Ekonomi, 2017; Kompas, 2018). The Minister of Education and Culture focuses the implementation of zoning system in an area which do not have quality schools. This zoning system id not only for New Students Admission but for all programs that the main aim is to accelerate the equal distribution of the quality education in Indonesia, from early childhood, elementary, junior high, senior high, vocational school and other education level.

b. To eliminate school castration, namely the title of favorite school and non-favorite school (Warta Ekonomi, 2017). By this zoning system, it is hoped that every favorite school in certain area is not only there but rather equal to be everywhere. For sure, we will accelerate each zone to have favorite school. So the favorite school will be everywhere.

c. To create many favorite schools (Kompas, 2018)

d. Improving the quality of the teachers (Kompas 2018)

The intervention program is needed. It can be in the form of programs to improve the teachers quality, infrastructure, teaching and learning process, students' activities and others. According to Didik, there should be an intervention to schools, namely the schools that are close to National Education Standards. "and that will be intervened so that there are good schools in each zone".

e. Ensuring the access of services for students, then bringing the school environment closer to the family environment, then eliminating discrimination in schools especially in state schools (Detik News, 2018)

f. Improving school infrastructure and staffs (Detik News, 2018)

g. To accommodate students who cannot afford to get school (Detik News, 2017). This is actually an affirmation program to protect children who cannot afford to get to school especially state school because the school is founded by taxes.

In the third part: New Students Admission path, articles 16 (the regulations of Minister of Education and Culture No. 51 of 2018) stated that: New Students Admission registrations carried out through channels including:

a. Zones (at least $90 \%$ of the school capacity)

b. Achievement (at most $5 \%$ of the school capacity)

c. Transfer of duties of parents (at most $5 \%$ of the school capacity)

d. Prospective students can only choose 1 path from 3 lines of new students admission, only in 1 zoning

e. In addition to registration of new students admission through zoning route, prospective students can also register for new students admission by using achievement pathway for outside zoning

f. Schools run by local government are prohibited from opening the registration of new students admission outside the regulations of Minister of Education and Culture No. 51 of 2018. 
The Analysis the Coverage of Education Access in JHS Level Compared to Elementary School Graduates Based on Zoning System in Cimahi.

How to analyze the coverage of education access at JHS level cpmared to elementary school graduates based on zoning system in Cimahi can be seen through this table:

Table 7. Analysis of Coverage of Education Access

\begin{tabular}{|c|c|c||c|}
\hline Zone & $\begin{array}{c}\text { Students } \\
\text { number in } \\
\text { class 6 }\end{array}$ & $\begin{array}{c}\text { Number } \\
\text { of JHS } \\
\text { units }\end{array}$ & Capacity \\
\hline 1 & 825 & 1 & 396 \\
\hline 2 & 504 & 1 & 324 \\
\hline 3 & 572 & 1 & 396 \\
\hline 4 & 707 & 1 & 324 \\
\hline 5 & 578 & 1 & 396 \\
\hline 6 & 393 & 1 & 396 \\
\hline 7 & 2.180 & 2 & 648 \\
\hline 8 & 624 & 2 & 540 \\
\hline 9 & 750 & 1 & 324 \\
\hline $\begin{array}{c}\text { Total } \\
\text { Number }\end{array}$ & $\mathbf{7 . 1 3 3}$ & $\mathbf{1 1}$ & $\mathbf{3 . 7 4 4}$ \\
\hline
\end{tabular}

From the table above, it can be seen that the number of prospective elementary graduates for $201 / 2020$ school year is still to many to be accommodated in JHS zone. From the nine zones there are 3,389 (47,51\%) students who have not been accommodated at JHS in Cimahi, it is equal to 95 class groups where 1 class group can accommodate only 36 students. Based on the regulations of Minister of Education and Culture No. 51 of 2018. It means, if the government of Cimahi wants a policy that elementary graduates should be accommodated in JHS, it requires the provision of new classes (new school units) which is equal to 95 classes.

The comparison chart of the number of elementary graduates who can be accommodated and those who are not can be seen through this graphic: 


\section{Analysis of Coverage of Education Access}

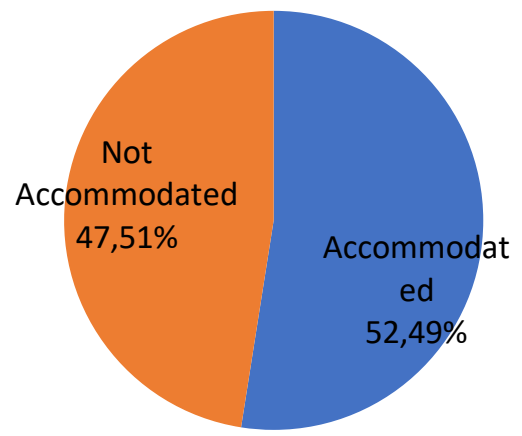

Graphic 1. The comparison chart of the number of elementary graduates who can be accommodated and those who are not

\section{DISCUSSION}

\section{Junior High Schools Units in Cimahi}

Junior High School, hereinafter abbreviated as JHS, is a form of formal education unit that provides general education at the basic level as a continuation of Elementary School, Madrasah Ibtidaiyah or other form of learning outcomes that are recognized as equivalent to Elementary School (as the regulations of Minister of Education and Culture No. 51 of 2018). Class groups is a group that the students are registered in a certain unit oh JHS.

Based on the Regional Regulation Draft of Cimahi of 2018 concerning the Management and Implementation of Basic Education (Chapter III Article 33, 2018) the functions of JHS are:

1. Develop, live, and practice the values of recognized faith, morals, personalities.

2. Develop, live, and practice the values of the nation and love of the recognized country.

3. Learn the basics of science and technology.

4. Train and develop sensitivity and ability to appreciate and express beauty, refinement and harmony.

5. Develop talents and abilities in the fields of arts, culture and sports, both for selfdevelopment, character building and achievement.

6. Develop physical and mental readiness to continue education to upper level.

The purpose of JHS is to build a foundation for the development of the potential students to become human beings who:

1. Have faith and fear in God Almighty, have good character and personality.

2. Intelligent, competent, critical, creative and innovative.

3. Healthy, independent, and confident. 
4. Tolerant, socially sensitive, democratic, and responsible.

\section{Zoning Rules for Elementary School Students to Enroll Junior High Schools in Cimahi}

New Student Admission is carried out based on the regulations of Minister of Education and Culture No. 51 of 2018 which are:

1. Non-discriminative, except for school that serve students from certain gender or religious groups.

2. Objective

3. Transparent

4. Accountable

5. Fair

The requirements for new students in seventh grade of JHS are:

1. At the maximum age of 15 on July 1 of the current year. It should be proven by birth certificate which is issued by the authority and legalized by the head of the birth place.

2. Having a certificate of completion mark of Elementary Schools

There are several things that become a reference for zoning regulations as it is stated in the regulations of Minister of Education and Culture No. 51 of 2018 such as:

1. Based on the domicile of the students

2. Choice of the closest school

3. School capacity

4. Pre-prosperous and general selection types

(Letter of National Examination Results for JHS is currently no longer a requirement in New Students Admission)

The objectives of zoning system in Elementary School to enroll to JHS in Cimahi are as follows:

1. For equality of receiving rights of education for children at age school to obtain quality education (Warta Ekonomi, 2017; Kompas, 2018). The Minister of Education and Culture focuses the implementation of zoning system in an area which do not have quality schools. This zoning system is not only for New Students Admission but for all programs that the main aim is to accelerate the equal distribution of the quality education in Indonesia, from early childhood, elementary, junior high, senior high, vocational school and other education level.

2. To eliminate school castration, namely the title of favorite school and non-favorite school (Warta Ekonomi, 2017). By this zoning system, it is hoped that every favorite school in certain area is not only there but rather equal to be everywhere. For sure, we will accelerate each zone to have favorite school. So the favorite school will be everywhere.

3. To create many favorite schools (Kompas, 2018)

4. Improving the quality of the teachers (Kompas 2018) 
5. The intervention program is needed. It can be in the form of programs to improve the teachers quality, infrastructure, teaching and learning process, students' activities and others. According to Didik, there should be an intervention to schools, namely the schools that are close to National Education Standards. "and that will be intervened so that there are good schools in each zone".

6. Ensuring the access of services for students, then bringing the school environment closer to the family environment, then eliminating discrimination in schools especially in state schools (Detik News, 2018)

7. Improving school infrastructure and staffs (Detik News, 2018)

8. To accommodate students who cannot afford to get school (Detik News, 2017).

9. This is actually an affirmation program to protect children who cannot afford to get to school especially state school because the school is founded by taxes and it should be returned to the people, that is the zone.

Each policy that is implemented followed some considerations because it has several advantages. The advantages itself such as (Dikpora, 2017):

1. Creating equity

2. Intelligent students do not only in favorite schools

3. The quality of the school can be seen

4. Non-favorite schools also have the opportunity to challenge their students to foster their students with extraordinary achievements.

5. Non favorite schools also have the opportunity to show that they can be the same as favorite school.

6. It is because the funds from the government is equal for each school, so the opportunity is also the same. A different thing may be the funding contribution from the students' parents. Parents in favorite schools are easier to be asked to work cooperatively to improve school facilities. Students in favorite schools are generally easier to get invited to move forward because of the their high enthusiasm for learning and compete for achievement.

7. To improve school infrastructure and also the staffs (Detik News, 2018)

8. Encouraging community participation through School Committee in the role and quality of education. These grants or donations can be used to cover the shortage of educational unit costs, financing activities in terms of improving school quality, developing facilities and infrastructure, and financing the operational activities of the school committee.

9. To foster the equality of education quality.

10. Students with economically and academically low can access schools that have been fought over by the students who live far from school. The hope is that one day all schools can favorite schools.

11. Students who live within the zone can get bigger opportunities to be accepted.

Meanwhile, for the shortcomings of zoning system itself should be overcome such as: 
1. Students in lower education units become lazy due to they already known that there is no selection to be accepted in that school

2. Weaken students' enthusiasm to compete

3. Unreadiness of the students with the new system

4. Lack of socialization makes them not ready yet with the new system

5. There is a tendency from the parents of the students to select private and quality school for their children then enrolling them to the schools that are considered not good in the zone itself.

6. Private schools are considered to be chosen by parents

\section{The Implementation of Zoning System in Education in Several Countries}

The implementation of zoning system in Indonesia follows Italy and Japan that previously do the same thing.

In Japan, the parents are seldom take their children to school by car. They prefer accompany their children on foot walking together and the bond between them is clearly seen (Koesoema, 2018).

In Italy, enrolling JHS without any test, students may choose what department they like most. It is because the curriculum in JHS studies many foreign language such as: English, German, French and Spanish. It is usually students in Elementary Schools will meet again when they are in JHS, especially when they get the same major of foreign language. In addition, the education system in Italy does not recognize any class rank, while report is only a summary of all daily scores that are distributed as the end of the odd semester and even semester (Iyus, 2018)

\section{CONCLUSION}

The conclusions of this study are as follows:

a. There is insufficient coverage to education access at state JHS compared to the number of Elementary graduates within the zone.

b. Form the nine zones in zoning map, there is only zone 6 which can accommodated Elementary graduates in state JHS

c. There are many elementary graduates for the 201/2020 school year not accommodated in state JHS within the zone.

Therefore from this result of the study recommends that there is still a need to increase the number of class units for state JHS that refers to laws and regulations in order to reorganize the rules or zoning system in Cimahi as a regulation from the Mayor.

\section{REFERENCES}

Abidin, M. Z \& Asrori . (2018). Peranan Sekolah Kawasan Berbasis Sistem Zonasi dalam Pembentukan Karakter di SMP Negeri 15 Kedung Cowek, Surabaya. Jurnal Pendidikan Islam. Vol. 7, No. 1 Tahun 2018. 
Budi Koestoro. Karakteristik Pendidikan Dasar (SD Dan SMP) Di Kota Kupang Provinsi Nusa Tenggara Timur. Jurnal Ekonomi \& Pendidikan. Vol.4 No.1 April 2007.

Detik News. 25 Juni 2018. Mendikbud: PPDB Pakai Sistem Zonasi agar Sekolah Dekat Keluarga.https://news.detik.com/berita/4082734/mendikbud-ppdb-pakaisistem-zonasi-agar-sekolah-dekat-keluarga

Detik News. 06 Juli 2017.Alasan Kemendikbud Terapkan Sistem Zonasi dalam PPDB. https://news.detik.com/berita/d-3550199/alasan-kemendikbud-terapkansistem-zonasi-dalam-ppdb

Depdikbud NTB. (2018). Ppt: PPDB SMA SMK SLB NEGERI2018/2019.

Iyus R (2018) Mengenal Italia Lebih Dekat: Sekilas Tentang Pendidikan Di Itali. Tersedia di: https://www.indovoices.com/pendidikan/mengenal-italia-lebihdekat-sekilas-tentang-pendidikan-di-italia/ I Indovoices. [Diunduh tanggal 24 Juli 2019].

Khadowmi, E. R. (2019). Implementasi Kebijakan Sistem Zonasi terhadap Proses Penerimaan Peserta Didik Baru Kabupaten Lampung Tengah. Skripsi Unila Bandar Lampung: Tidak dipublikasikan.

Koesoema, D.A. (2018). Tantangan Kebijakan Zonasi. Diakses dari:

https://mediaindonesia.com/read/detail/176704-tantangan-kebijakan-zonasi. [Diunduh tanggal 23 Juli 2019].

Komariah, A \& Satori, D. (2011).Metode Penelitian Kualitatif. Bandung: Alfabeta.

Kompas. 15/10/2018. Tenyata Ini 3 Tujuan Zonasi Selain untuk PPDB. https://edukasi.kompas.com/read/2018/10/15/18530531/tenyata-ini-3-

tujuan-zonasi-selain-untuk-ppdb.

Media Komunikasi dan Inspirasi: Jendela Pendidikan dan Kebudayaan. (2017). Sistem

Baru Penerimaan Peserta Didik Baru. Edisi XII/ Juli 2017

McCulloch, G (1991). School zoning, equity and freedom: the case of New Zealand.Journal of Education Policy. Volume 6, 1991 - Issue 2, Pages 155-168

Mustholih (2019). Siswa Terdekat Sekolah Wajib Diterima. Diakses dari:

https://www.medcom.id/pendidikan/news-pendidikan/nbwQdAxK-siswa-

terdekat-sekolah-wajib-diterima. [Diunduh tanggal 22 Juli 2019].

Purwanti, D, Irawati, I, \& Adiwisastra, J. (2019). Efektivitas Kebijakan Penerimaan Peserta Didik Baru Sistem Zonasi Bagi Siswa Rawan Melanjutkan Pendidikan The Effectiveness of New Student Admission of Zoning System Policy for Students Prone to Continue Education. Luaran Disertasi UNPAD Bandung: Artikel Jurnal,tersedia di: https://jurnal.unigal.ac.id/index.php/dinamika/article/.../1409. [Diunduh tanggal 4 Mei 2019].

Sahlberg, P (2007). Education policies for raising student learning: the Finnish approach. Journal of Education Policy. Vol. 22, No. 2, March 2007, pp. 147-171

Sukmadinata, N. S. (2011). Metode Penelitian Pendidikan. Bandung: PT Remaja Rosdakarya. 
Warta Ekonomi. Kamis, 13 Juli 2017 Ini Tujuan Penerapan Sistem Zonasi Sekolah,Kata Mendikbud.https://www.wartaekonomi.co.id/read147389/ini-tujuanpenerapan-sistem-zonasi-sekolah-kata-mendikbud.html. Diambil pada Tanggal 23 April 2019.

Wali Kota Cimahi (2018). Draft Peraturan Daerah Kota Cimahi Nomor Tahun 2018.

Wulandari, D. (2018). Pengaruh Penerimaan Peserta Didik Baru melalui Sistem Zonasi terhadap Prestasi Belajar Siswa Kelas VIIdi SMP N 1 Labuhan Ratu Lampung Timur Tahun Pelajaran 2017/2018. Skripsi Unila Bandar Lampung: Tidak dipublikasikan.

\section{Undang Undang/Peraturan}

Permendikbud No.17 Tahun 2017 Tentang Penerimaan Peserta Didik Baru (PPDB). Permendikbud No. 51 Tahun 2018 Tentang Penerimaan Peserta Didik Baru (PPDB). Permendikbud No. 14 Tahun 2018 Tentang Penerimaan Peserta Didik Baru (PPDB) 